\title{
HUBUNGAN ANTARA PENDIDIKAN DALAM KELUARGA DENGAN SIKAP RASA HORMAT SISWA KELAS IV SD NEGERI O3 KOTA PAGAR ALAM
}

\author{
Frizka Wahyuni \\ Program Studi PGSD FKIP Universitas Bengkulu \\ Dalifa \\ Program Studi PGSD FKIP Universitas Bengkulu \\ Abdul Muktadir \\ Program Studi PGSD FKIP Universitas Bengkulu
}

\begin{abstract}
Abstrak
Penelitian ini bertujuan untuk mengetahui hubungan antara pendidikan dalam keluarga dengan sikap rasa hormat siswa kelas IV SD Negeri 03 Kota Pagar Alam. Jenis penelitian ini adalah penelitian kuantitatif dengan metode korelasional. Populasi dalam penelitian ini adalah seluruh siswa kelas IV SDN 03 Kota Pagar Alam. Sampel yang diambil pada penelitian ini berjumlah 35 orang yang diambil melalui pengambilan Simple Random Sampling. Instrumen penelitian menggunakan lembar angket. Teknik analisis data yang digunakan adalah uji hipotesis dengan menggunakan korelasi Product Moment. Hasil uji hipotesis menunjukan bahwa ${ }_{\text {rnitung }}(0,515)>$ rtabeldengan taraf signifikan $5 \%$ $(0,334)$ maka antara Variabel $\mathrm{X}$ dan Variabel $\mathrm{Y}$ memiliki hubungan yang cukup kuat sehingga $\mathrm{H}_{\mathrm{a}}$ diterima, artinya terdapat hubungan cukup kuat antara pendidikan dalam keluarga dengan sikap rasa hormat siswa kelas IV SDN 03 Kota Pagar Alam. Dengan uji signifikasi (t) didapatkan hasil bahwa hubungan pendidikan dalam keluarga dengan sikap rasa hormat memiliki hubungan yang signifikan. Selanjutnya hasil dari perhitungan statistik diperoleh sumbangan variabel X terhadap Y sebesar $r^{2}=0,2652$ sehingga dapat disimpulkan bahwa pendidikan dalam keluarga memberikan kontribusi sebesar 26,52\% terhadap sikap rasa hormat siswa kelas IV SDN 03 Kota Pagar Alam.
\end{abstract}

Kata Kunci: Pendidikan dalam keluarga, sikap rasa hormat.

\section{PENDAHULUAN}

Moral dilandasi oleh beberapa nilai yang menggabung menjadi satu dan menjadi kebiasaan. Kemudian nilai-nilai tersebut membentuk seseorang menjadi pribadi yang baik dan pribadi yag bisa diterima di lingkungan. Borba (2008:150) menyatakan bahwa kebajikan yang sangat penting bagi setiap individu ialah rasa hormat, karena seseorang akan memperlakukan orang lain sebagaimana seseorang tersebut mengharapkan orang lain memperlakukannya. Ditambahkan oleh Lickona (2013:61) yang mengungkapkan bahwa ada dua nilai moral dasar yaitu, sikap hormat dan tanggung jawab. Kedua nilai inilah yang membentuk inti dari moralitas publik universal. Jadi dapat disimpulkan bahwa rasa hormat begitu penting karena merupakan landasan dari sikap moral lainnya dan merupakan sikap penghargaan kepada orang lain sebagaimana ia ingin diperlakukan orang lain pula.

Pudarnya rasa hormat yang melandasi sikap moral anak akan menimbulkan dampak negatif. Saat ini rasa menghormati kepada orang lain tak lagi terlihat seperti dulu. Anak sudah acuh tak acuh kepada orang yang lebih tua, jarang memberi salam, jarang membantu orang tua yang butuh bantuan, jarang mau mendengarkan nasihat orang yang lebih tua, dan kadang memperlakukan orang orang yang lebih tua seperti temannya sendiri tanpa batasan hormat di dalamnya. Hal ini mengakibatkan terkikisnya etika terhadap orang yang lebih tua.

Kondisi memudarnya sikap hormat saat 
ini sangat memprihatinkan. Bila kemerosotan ini terus dibiarkan maka akan berakibat fatal, lama kelamaan bangsa Indonesia akan menjadi bangsa yang agresif dan tidak bermoral sehingga akan ada banyak penindasan, perampasan, dan ketidakadilan. Hal yang bisa dilakukan untuk mencegah pudarnya rasa hormat dan moral anak adalah dengan menanamkan dan membentuk nilai-nilai moralitas pada diri anak sejak dini sehingga terbentuk jiwa pribadi yang bermoral dan hormat pada diri anak. Kepribadian anak itu terbentuk dan berlangsung di dalam pendidikan dalam keluarga, pendidikan dalam lingkup sekolah, dan pendidikan dalam masyarakat. Dari beberapa lingkup yang berpengaruh terhadap pembentukan nilai moral anak, keluargalah yang paling mempengaruhi pembentukan moral anak.

Hal ini sejalan dengan pendapat Purwanto (2007:79) yang menyatakan bahwa pendidikan keluarga merupakan fundamen atau dasar dari pendidikan anak selanjutnya. Hasil-hasil dari pendidikan yang diperoleh anak dalam keluarga menentukan pendidikan anak selanjutnya, baik di sekolah maupun dalam masyarakat. Hasbullah (2009:38) mengungkapkan bahwa orang yang pertama dan bertanggung jawab terhadap kelangsungan hidup dan pendidikan anak yaitu keluarga. C.G Salzaman dalam Purwanto (2007:80) mengecam bahwa segala kesalahan anak merupakan akibat dari perbuatan pendidik-pendidiknya. Oleh karena itu, keluarga berperan penting dalam pembentukan sikap anak. Untuk memiliki sikap moral yang tinggi seseorang tidak bisa melakukannya sendiri melainkan harus didukung oleh semua pihak yang ada disekitar. Di dalam kehidupan anak, sikap moral diperoleh dengan berbagai cara salah satunya melalui pendidikan dalam keluarga.

$$
\text { Pendidikan dalam keluarga }
$$
mengajarkan bagaimana anak harus menyikapi hidup bermasyarat, menghadapi permasalahan sosial yang berkaitan dengan kehidupan sehari-hari. Sehingga anak mampu berhadapan secara baik dan diterima dimasyarakat.

$$
\text { Comenius dalam Purwanto }
$$

(2007:79) menegaskan bahwa pentingnya pendidikan dalam keluarga dimana tingkatan permulaan bagi pendidikan anak dilakukan dalam keluarga, sehingga keluarga harus mendidik anak-anaknya dengan bijaksana, mememuliakan Tuhan dan untuk keselamatan jiwa anaknya.

Hasbullah (2009:39) mengemukakan bahwa fungsi dan peran pendidikan keluarga meliputi pengalaman pertama masa kanak-kanak, menjamin kehidupan emosional anak, menanamkan dasar pendidikan moral, memberikan dasar pendidikan sosial, dan peletakan dasardasar keagamaan. Dari beberapa peranan tersebut peneliti hanya akan melakukan penelitian mengenai pendidikan dalam

keluarga menanamkan dasar pendidikan moral saja. Hal ini disesuaikan dengan kebutuhan peneliti.

$$
\text { Pada masa praobservasi, }
$$

terkikisnya moral terutama sikap rasa hormat anak juga tampak di SDN 03 Kota Pagar Alam. Peneliti menemukan ada anak-anak yang tutur katanya kurang sopan, kurang menghargai orang yang lebih tua, suka mencemooh, suka mengganggu temantemannya, suka berkata kasar, dan suka berkelahi. Hal ini terlihat terutama pada anak yang berada di kelas IV.

\section{METODE}

Jenis penelitian yang digunakan pada penelitian ini adalah kuantitatif dengan metode penelitian yaitu penelitian korelasional. Penelitian kuantitatif adalah penelitian yang berlandaskan pada filsafat positivisme, digunakan untuk meneliti pada populasi atau sampel tertentu, pengumpulan data menggunakan instrumen penelitian, analisis data bersifat kuantitatif/statistik, dengan tujuan untuk menguji hipotesis yang telah ditetapkan (Sugiyono, 2013: 8). Penelitian korelasional adalah penelitian hubungan antara variabel atau beberapa variabel dengan variabel lain (Winarni, 2011: 46).

Populasi dalam penelitian ini adalah seluruh siswa kelas IV SDN 03 Kota Pagar Alam pada semester genap yang berjumlah 81 orang yang terdiri dari kelas IVA dengan jumlah siswa 39 orang dan kelas IVB dengan jumlah siswa 42 orang.

Sampel penelitian ini adalah siswa kelas IV dengan jumlah sampel 35 siswa yang terdiri dari kelas IVA sebanyak 15 orang dan IVB sebanyak 20 orang. Teknik yang digunakan untuk mengambil sampel pada penelitian ini adalah menggunakan 
teknik Simple Random Sampling.

Pengambilan anggota sampel dilakukan secara acak tanpa memperhatikan strata yang ada dalam populasi. Dalam pengambilan sampel, peneliti menggunakan cara undian.

Sedangkan sampel yang digunakan untuk uji coba instrumen adalah siswa kelas IVA dan IVB di SD Negeri 58 Kota Pagar Alam yang di pilih secara acak sebanyak 30 orang. SD Negeri 58 Kota Pagar Alam sebagai lokasi untuk uji coba instrumen karena memiliki akreditasi A dan lokasi SD tersebut berdekatan dengan SD Negeri 03 sehingga memiliki karakteristik yang sama.

Instrumen yang digunakan pada penelitian ini adalah lembar angket. Jenis

angket yang digunakan ialah angket tertutup dan langsung. Lembar angket digunakan untuk mengetahui pendidikan dalam keluarga dan sikap ras hormat yang dimiliki siswa. Teknik pengumpulan data yang digunakan dalam penelitian yaitu kuesioner (angket). Penyusunan angket menggunakan skala likert dengan lima pilihan jawaban yaitu: Sangat Sering (SSR), Selalu (S), Sering (SR), Jarang (J), dan Tidak Pernah (TP). Angket dinyatakan dengan dua pernyataan yaitu pernyataan positif dan penyataan negatif. Skor pernyataan positif jawaban 5 Sangat Sering (SSR), 4 Selalu (S), 3 Sering (SR), 2 Jarang (J), dan 1 Tidak Pernah (TP). Skor pernyataan negatif jawaban 1 Sangat Sering (SSR), 2 Selalu (S), 3 Sering (SR), 4 Jarang (J), dan 5 Tidak Pernah (TP).

$$
\text { Teknik analisis data yang }
$$

Digunakan dalam penelitian ini adalah analisa kuantitatif yang terdiridari analisis statistic deskriptif,analisis inferensial.

\section{HASIL}

Data penelitian ini meliputi data yang diperoleh dari pesebaran kuesioner dengan menggunakan skala sikap. Hasil penelitian menunjukkan bahwa nilai rata-rata pendidikan dalam keluarga sebesar 91,65 dan sikap rasa hormat sebesar 97,11. Median pendidikan dalam keluarga senilai 92,31 sedangkan sikap rasa hormat senilai 96,50. Modus pendidikan dalam keluarga sebesar 90 sedangkan modus sikap rasa hormat sebesar 100. Nilai tertinggi pendidikan dalam keluarga sebesar 110 sedangkan nilai terendah yang didapatkan sebesar 69. nilai tertinggi sikap rasa hormatsebesar 120 dan nilai terendah sebesar 76. Semakin sama nilai mean median modus suatu data maka semakin normal data tersebut.

Dilihat dari data pendidikan dalam keluarga dan sikap rasa hormat maka bisa disimpulkan kedua data tersebut normal. Semakin besar variannya maka semakin kecil homogenitas data, semakin besar varian maka semakin besar simpangan baunya. Dari pengujian standar simpangan baku didapatkan hasil pendidikan dalam keluarga sebesar 10,77 sedangkan untuk sikap rasa hormat sebesar 10,89 sehingga dapat disimpulkan bahwa data pendidikan dalam keluarga lebih homogen dari pada data sikap rasa hormat.

$$
\text { Pengujian normalitas pada }
$$

Penelitian ini imenggunakan rumus

Kolmogoriv smirnovdengan kriteria Jika nilai Dhitung terbesar e Dtabel, maka dinyatakan penyebaran data berdistribusi tidak normal. Jika nilai Dhitung terbesar < Dtabel, maka dinyatakan penyebaran data berdistribusi normal .Berdasarkan hasil uji normalitas menggunakan Kolmogorov Smirnov IFTFSIdidapatkan Dmaks untuk variabel pendidikan dalam keluarga sebesar 0,022. Sedangkan untuk variabel sikap rasa hormat Dmaks yang didapatkan sebesar 0,015. Dengan taraf signifikasi $5 \%$ dan $\mathrm{N}=35$ diperoleh Dtabel = 0,224 . Karena nilai DhitungIFT-FSI $<$ Dtabel maka dapat disimpulkan bahwa data berdistribusi

normal.

Setelah mencari kenormalan data selanjutnya adalah menentukan homogenitas data pada uji homogenitas juga didasarkan pada ketentuan pengujian hipotesis homogenitas yaitu jika nilai Fhitung < Ftabelmakakeduakelompoksampel dinyatakan memiliki varians yang homogendanjikaFhitung $>$ Ftabelmakakeduakel ompoksampeldinyatakan memiliki varians yangtidakhomogen.Berdasarkan hasil uji homogenitas sebesar 1,022. Pada taraf signifikasi $5 \%$ dengan $\mathrm{dk} 1=35$ dan $\mathrm{dk} 2=35$ diperoleh Ftabel $=1,84$. Karena nilai Fhitung $<$ Ftabel maka dapat disimpulkan bahwa hubungan antara variabel tersebut bersifat homogen.

Pengujian hipotesis penelitian ini, menggunakan teknik korelasi Product Moment. Uji ini untuk menguji hubungan antara pendidikan dalam keluarga (X) dengan sikap rasa hormat (Y) siswa kelas IV SD Negeri 
03 Kota Pagar Alam. Pengujian hubungan ini berdasarkan kriteria pengujian yaitu jika ${ }_{\text {rxy }}{ }^{\mathrm{e}}$ rtabel maka terdapat korelasi antara variabel $\mathrm{X}$ dan $\mathrm{Y}$. Namun jika $r x y<$ rtabelmaka tidak terdapat korelasi antara variabel $\mathrm{X}$ dan $\mathrm{Y}$. Dengan taraf signifikan $5 \%$ dan $\mathrm{n}=35$ maka diperoleh rtabel sebesar 0,334.

$$
\text { Hasil perhitungan data }
$$

menggunakan rumus kolerasi product moment agar bisa diketahui berapa besar koefisien korelasi antara variabel $\mathrm{X}$ dan variabel Y. Melalui perhitungan tersebut diperoleh hasil rxy atau rhitung sebesar 0,515 dengan taraf signifikan 5\% didapat ttabel sebesar 0,334. Dari hasil perhitungan yang telah dilakukan menunjukan bahwa rhitung ${ }^{A}$ rtabel, sehingga dapat dikatakan bahwa variabel $\mathrm{X}$ memiliki hubungan dengan variabel $\mathrm{Y}$ maka pendidikan dalam keluarga memiliki hubungan dengan sikap rasa hormat siswa kelas IV SDN 03 Kota Pagar Alam.

$$
\text { Berdasarkan hasil hipotesis }
$$

hubungan Pendidikan dalam keluarga dengan Sikap rasa hormat siswa kelas IV SD Negeri 03 Kota Pagar Alam menggunakan uji statistik diperoleh rxy $=0,515$, sumbangan yang diberikan oleh pendidikan dalam keluarga dihitung menggunakan penghitungan statistik $r^{2}=0,2652$ sehingga diperoleh hasil sumbangan pendidikan dalam keluarga terhadap sikap rasa hormat sebesar $26,52 \%$ dan signifikasi yang diberikan oleh pendidikan dalam keluarga dihitung menggunakan penghitungan statistik sehingga diperoleh hasil signifikasi pendidikan dalam keluarga terhadap sikap rasa hormat siswa kelas IV SDN 03 Kota Pagar Alam sebesar 3,451 .

Hasil analisis data penelitian tentang pendidikan dalam keluarga dengan sikap rasa hormat siswa kelas IV SDN 03 Kota Pagar Alam secara umum menunjukan hasil bahwa pesebaran data homogen dan normal. Pendidikan dalam keluarga mempunyai rata-rata data yang memiliki nilai reliabilitas tinggi dan termasuk dalam kategori sangat baik. Hal ini karena mean yang didapatkan tinggi sehingga masuk ke dalam kategori sangat baik. Hasil analisis data sikap rasa hormat menunjukan nilai mean yang tinggi sehingga bermakna reliabilitasnya tinggi dan terkategori sangat baik. Hal ini selaras dengan pendapat Hariyadi (2009:55) yang menyebutkan bahwa mean tinggi maka reliabilitasnya tinggi pula.
Hasil pengujian normalitas pendidikan dalam keluarga menunjukan Dhitung terbesar sebesar 0,022 dan Dtabel sebesar 0,224. Hal ini berarti bahwa pendidikan dalam memiliki data yang normal karena Dhitung terbesar lebih besar dibandingkan dengan Dtabel. Hasil pengujian normalitas sikap rasa hormat menunjukan Dhitung terbesar sebesar 0,015 dan Dtabel dengan taraf signifikan 5\% sebesar 0,224. Hal ini berarti bahwa sikap rasa hormat memiliki data yang normal karena Dhitung terbesar lebih besar dibandingkan dengan Dtabel. Hasil uji homogenitas pendidikan dalam keluarga dan sikap rasa hormat fhitung sebesar 1,022 dengan ftabel dengan taraf signifikan 5\% sebesar 1,84. Ini menunjukan bahwa fhitung < ftabel maka distribusi data homogen sehingga dapat disimpulkan bahwa data pendidikan dan sikap rasa hormat berdistribusi homogen. Hasil uji korelasi antara pendidikan dalam keluarga dengan sikap rasa hormat didapatkan rhitung sebesar 0,515 sedangkan rtabel dengan taraf signifikan 5\% sebesar 0,334. Dapat dilihat bahwa rhitung ${ }^{\tilde{A}}$ rtabel, hal ini berarti bahwa variabel $X$ berhubungan dengan varibabel $\mathrm{Y}$ sehingga dapat disimpulkan bahwa pendidikan dalam keluarga memiliki hubungan dengan sikap rasa hormat siswa kelas IV SD Negeri 03 Kota Pagar Alam.

Uji signifikan variabel $\mathrm{X}$ dan $\mathrm{Y}$ menunjukan thitung sebesar 3,451 dengan ttabel dengan taraf signifikan 5\% sebesar 2,042. Dapat dilihat bahwa thitung $\tilde{\AA}$ ttabelhal ini bermakna bahwa variabel $X$ memiliki hubungan signifikan terhadap variabel $\mathrm{Y}$ sehingga dapat disimpulkan bahwa pendidikan dalam keluarga memiliki hubungan signifikan dengan sikap rasa hormat siswa kelas IV SD Negeri 03 Kota Pagar Alam.

\section{PEMBAHASAN}

Dari hasil pengujian di atas dapat disimpukan bahwa Ha diterima artinya terdapat hubungan signifikan antara pendidikan dalam keluarga dengan sikap rasa hormat siswa kelas IV SDN 03 Kota Pagar Alam dengan kategori hubungan yang sedang atau cukup kuat. Hasil penelitian ini selaras dengan hasil penelitian Rosalia (2015) yang menyimpulkan bahwa pendidikan dalam keluarga memberikan pengaruh terhadap moral anak. 
Keluarga merupakan tempat yang yang paling baik untuk membentuk sikap anak. Anak dari bayi sampai dewasa dididik untuk menjadi pribadi yang baik dan bermoral. Dari keluarga anak mengalami masa sosialisasi pertama. Dari keluarga anak mendapati pengalaman pertama, dan dari keluarga pula anak mendapati ajaran moral dan etika pertama kali. Hal ini selaras dengan pendapat Hasbullah (2009:38) yang menyatakan bahwa keluarga merupakan lingkungan pendidikan yang pertama dan utama karena dalam keluarga anak pertama-tama mendapatkan didikan juga sebagian besar dari kehidupan anak ada di dalam keluarga.

Semakin dini anak diajarkan tentang moralitas dan sikap rasa hormat maka anak akan semakin memahami makna dari pengajaran tersebut. Semakin paham anak akan arti moral dan rasa hormat maka akan terbentuk nilai dalam diri anak sehingga akan semakin menunjang sikap moral anak. Anak yang telah memiliki nilai hormat di dalam dirinya a ka n menampakan nilai tersebut melalui sikap anak dikehidupan sehari-hari.

Hal yang harus dilakukan orang tua dalam proses pembentukan moral anak sampai pada fase tindakan moral yaitu dengan melakukan melakukan pembiasaan. Semakin baik pendidikan yang diberikan oleh keluarga maka semakin baik pula sikap anak, begitu pula sebaliknya. Hal ini selaras dengan pendapat Purwanto bahwa pendidikan keluarga adalah fundamen atau dasar dari pendidikan anak selanjutnya. Hal ini sejalan dengan pendapat Syarbini (2014:87) yang menyatakan bahwa pembiasaan yang dilakukan sejak

dini/sejak kecil akan membawa kegemaran dan kebiasaan tersebut menjadi semacam adat kebiasaan sehingga menjadi bagian yang tidak terpisahkan dari kepribadiannya.

\section{SIMPULAN}

Berdasarkan hasil penelitian dan pembahasan dapat disimpulkan bahwa terdapat hubungan yang signifikan antara pendidikan dalam keluarga dengan sikap rasa hormat siswa kelas IV SD Negeri 03 Kota Pagar Alam.

\section{SARAN}

1. Bagi keluarga, khususnya orang tua dalam memberikan pendidikan moral yang melewati tiga fase yaitu pengetahuan moral, perasaan moral, dan tindakan moral, harus menjadi teladan bagi anak dengan menggunakan metode pembiasaan kepada anak agar nilai-nilai yang diajarkan melekat di diri anak dan menjadi kebiasaan anak.

2. Bagi guru, hendaknya guru mengoptimalkan kolaborasi kerjasama bersama orang tua untuk memunculkan kebiasaan positif anak yang telah didapatkan anak di lingkungan keluarga dan pengalaman teman sehingga guru bisa memotivasi anak untuk terus melakukan kebiasaan yang positif.

3. Bagi siswa, diharapkan untuk melatih diri dengan kebiasaankebiasaan baik yang telah didapatkan di lingkungan keluarga, sekolah, teman, dan masyarakat.

\section{DAFTAR PUSTAKA}

Adisusilo, sutarjo. 2012. Pembelajaran Ni l a $i$ Nilai Karakter Konstruktivisme Dan VCT Sebagai Inovasi Pendekatan Pembelajaran Afektif. Jakarta: Rajawali Pers.

Ahmadi, Abu. 2004. Sosiologi Pendidikan. Jakarta: PT Asdi Mahasatya.

Azwar, Saifuddin. 2015. Sikap Manusia Teori dan Pengembangannya. Yogyakarta: Pustaka Pelajar.

Borba, Michele. 2008. Membangun Kecerdasan Moral. Diterjemakan oleh: Lina Jusuf. Jakarta: PT. Gramedia Pustaka Utama.

Desmita. 2012. Psikologi Perkembangan Peserta Didik. Bandung: PT

Fakultas Keguruan dan Ilmu Pendidikan. 2016. Pedoman Penyusunan Skripsi Revisi Kelima PGSD. FKIP Universitas Bengkulu. Bengkulu.

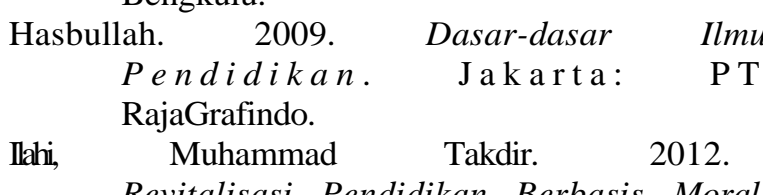
Revitalisasi Pendidikan Berbasis Moral. Jogjakarta: Ar-ruzz Media.

2014. Gagalnya

Pendidikan Karakter: Analisis dan Solusi Penngendalian Karakter Emas Anak Didik. Yogyakarta: Arruzz Media.

Kurniawan, Syamsul. 2016. Pendidikan Karakter 
Konsepsi \& Implementasi secara Terpadu di Lingkungan Keluarga, Sekolah, Perguruan Tinggi, dan Masyarakat. Jakarta : Ar-Ruzz Media.

Lickona, Thomas. 2013. Pendidikan Karakter:Panduan Lengkap Mendidik Siswa Menjadi Pintar dan Baik. Diterjemahkan oleh: Litas S. Bandung: Nusa Media.

Purwanto, M. Ngalim. 2004. Ilmu Pendidikan Teoritis dan Praktis. Bandung: PT Remaja Rosdakarya.

Sugiyono. 2013. Metode Penelitian Pendekatan Kuantitatif, Kualitatif, dan $R \& D$. Bandung: Alfabeta.

Sugiyatno. 2013. Optimalisasi Peran Keluarga dalam Membangun Moral Anak." Jurnal Kependidikan. Hlm.5-25.

Suyanto. 2016. Urgensi Pendidikan Karakter. Jakarta : Kompas.

Syarbini, Amirullah. 2014. Model Pendidikan Karakter dalam Keluarga. Jakarta: PT Elex Media Komputindo.

Tafsir, Ahmad. 2007. Ilmu Pendidikan Dalam Perspektif Islam. Bandung: Remaja Rosdakarya.

Winarni, E. W. 2011. Penelitian
Pendidikan. Begkulu: Putri Media. .

2011. Bahan Ajar Statistik.

FKIP. Universitas Bengkulu. Bengkulu.

Hardiyati, artis. 2015. 10 nilai-nilai positif yang penting diajarkan pada anak usia dini. Diakses pada tangal 5 februari 2017. www.solusisehatku.com/nilai-

moral-yang-penting-diajarkan-pada-anak-sejakusia-dini.html.

Hidayat, Anwar. 2013. Penjelasan rumus kolmogorof smirnov uji normalitas. Diakses pada tanggal 8 April 2017.

http://www.statistikian.com/2013/0 1/rumuskolmogorof-smirnov-html.

Komarudin, Asep (2017). Nilai moral yang penting untuk diajarkan pada anak-anak sejak usia dini. Diakses pada tanggal 5 Februari 2017.

www.ummi-online.com/10- nilainilai-positifyang-perlu-ditanamkan-kepada-anaksejak-dini.html.

Pribadi, Wasis Nanang. 2013. Bentuk bentuk Keluarga. Diunduh pada tanggal 06 Februari 2017. http://wasirpribadi.blogspot.co.id/2 013/03/normal.html. 